\title{
MANAJEMEN BIMBINGAN DAN KONSELING DI SMA MELATI BINJAI TAHUN PELAJARAN 2016/2017
}

\author{
Mulianta Ginting, Ali Daud Hasibuan, Arifin Jamil \\ STKIP Budidaya Binjai
}

\begin{abstract}
Abstrak
Pendidikan formal sebagai penyelenggara pendidikan yang telah diatur dalam undang-undang sistem pendidikan nasional berfungsi sebagai wadah bagi setiap individu Indonesia untuk dapat secara aktif mengembangkan fotensi dirinya untuk memiliki kecerdasan, kemandirian, pengendalian diri, akhlak mulia, dan keterampilan yang berguna bagi dirinya, masarakat bangsa dan negara. Dalam penelitian ini secara subtansi digunakan untuk menguraikan, menggambarkan, menggali serta mendiskripsikan tentang manajemen BK di SMA MELATI Binjai. Jenis penelitian lapangan adalah (field research) dengan pengamatan dan mencari data secara langsung ke lokasi dan objek yang diteliti. Penelitian ini merupakan penelitian deskriptif yang menggunakan pendekatan kualitatif dengan menempatkan peneliti sebagai instrumen utama dan penelitian yang ditujukan untuk mendeskripsikan dan menganalisa fenomena, peristiwa, aktivitas sosial, sikap, kepercayaan, persepsi, pemikiran orang secara individual maupun kelompok. Maksud penilaian adalah segala upaya, tindakan atau proses untuk menentukan derajat kualitas kemajuan kegiatan yang berkaitan dengan pelaksanaan program bimbingan dengan mengacu pada kriteria atau patokan-patokan tertentu sesuai dengan program bimbingan yang dilaksanakan.Kriteria/patokan yang dipakai untuk menilai keberhasilan pelaksanaan program pelayanan bimbingan dan konseling mengacu pada ketercapaian kompetensi, keterpenuhan kebutuhan-kebutuhan siswa dan pihak-pihak yang terkait langsuung maupuan tidak langsung yang berperan membantu siswa memperoleh perubahan secara keseluruhan dan partisipasi ke arah yang lebih baik.Akhirnya, secara keseluruhan pelayanan bimbingan dan konseling, penilaian bertujuan untuk memperoleh umpan balik terhadap keefektifan pelayanan bimbingan dan konseling yang telah dilaksanakan.

kata kunci : manajemen, bimbingan dan konseling
\end{abstract}

\section{PENDAHULUAN}

Peningkatan sumber daya manusia Indonesia sesungguhyna ditopang oleh pendidikan yang bermutu, yaitu pendidikan yang saling mendukung antara lembaga pendidikan formal, informal dan non formal. Pendidikan formal sebagai penyelenggara pendidikan yang telah diatur dalam undang-undang sistem pendidikan nasional berfungsi sebagai wadah bagi setiap individu Indonesia untuk dapat secara aktif mengembangkan fotensi dirinya untuk memiliki kecerdasan, kemandirian, pengendalian diri, akhlak mulia, dan keterampilan yang berguna bagi dirinya, masarakat bangsa dan negara. Oleh karna itu, pendidikan yang bermutu dalam penyelenggaraannya tidak cukup hanya dilaksanakan melalui transformasi ilmu pengetahuan dan teknologi semata, tetapi harus didukung dengan upaya profesionalisasi dan sistem manajemen yang handal demi tercapainya tujuan yang diharapkan.

Para ahli dan praktisi pendidikan dan semua stake-holders telah lama menegaskan kepada pihak sekolah betapa pentingnya menjalankan fungsinya secara penuh untuk lebih 
memungkinkan para siswa lebih mampu menghadapi tantangan masa depan yang semakin kompetitif. Artinya selain sekolah perlu menciptakan suasana pembelajaran yang lebih relevan dengan dimensi pengembangan manusia seutuhnya, sekolah juga hendaknya memperhatikan pula besarnya tantangan yang dihadapi para siswa agar mereka mampu mengatasi segala permasalahan yang dihadapi.

Saat ini keprihatinan tentang rendahnya mutu pendidikan di sekolah-sekolah kita memang masih faktual di lapangan, walaupun secara fisik pembangunan pendidikan kita sudah menunjukkan suatu kemajuan yang signifikan dengan semakin meningkatkan daya tampung sekolah-sekolah saat ini. Namun peningkatan daya tampung ini tidak berjalan secara seimbang dengan peningkatan mutu, baik dari sisi mutu proses pembelajarannya, maupun mutu sarana dan prasaranana, dan bahkan kompleksnya permasalahan yang dialami para siswa dalam beberapa kasus sudah mengalahkan pembelajaran yang baik sekalipun.

Kondisi ini jelas merupakan tantangan besar bagi upaya pembentukan manusia Indonesia seutuhnya yang menghendaki akan pengembangan secara optimal dalam hal individualitas, sosialitas, moralitas dan religiusitas. Bimbingan dan konseling sebagai pelayanan ang disediakan di sekolah untuk membantu siswa dalam mengembangkan fotensi yang dimiliki siswa hendaknya dilakukan manajemen dan penataan ang lebih handal, terarah, dan sistematis.

Para peserta didik di tingkat SLTA sebagian besar adalah remaja awal yang memiliki karakteristik, dan tugas-tugas perkembangan yang harus dipenuhi. Adapun tugas-tugas perkembangan peserta didik SLTA adalah sebagai berikut: 1) Mencapai perkembangan diri sebagai remaja yang beriman dan bertaqwa kepada Tuhan Yang Maha Esa, 2) Mempersiapkan diri, menerima dan bersikap positif serta dinamis terhadap perubahan fisik dan psikis yang terjadi pada diri sendiri untuk kehidupan yang sehat, 3) Mencapai pola hubungan yang baik dengan teman sebaya dalam peranannya sebagai pria atau wanita, 4) Memantapkan nilai dan cara bertingkah laku yang dapat diterima dalam kehidupan sosial yang lebih luas, 5) Mengenal kemampuan, bakat, minat, serta arah kecenderungan karier dan apresiasi seni, 6) Mengembangkan pengetahuan dan ketrampilan sesuai dengan kebutuhannya untuk mengikuti dan melanjutkan pelajaran dan mempersiapkan karir serta berperan dalam kehidupan masyarakat, 7) Mengenal gambaran dan mengembangkan sikap tentang kehidupan mandiri secara emosional, sosial, dan ekonomi, 8) Mengenal sistem etika dan nilai-nilai bagi pedoman hidup sebagai pribadi, anggota masyarakat, dan minat manusia.

Kedelapan tugas perkembangan peserta didik SLTA itu merupakan kompetensi yang harus dikuasai secara optimal. Untuk pencapaian kompetensi secara optimal ini diperlukan 
kerjasama tiga pilar pendidikan yakni manajemen, proses pembelajaran, dan bimbingan dan konseling. Layanan bimbingan dan konseling di SLTA tidak mungkin terselenggara dengan baik, dan pencapaian kompetensi yang harus dimiliki peserta didik sulit diupayakan apabila tidak memiliki manajemen bermutu, dan tidak dilakukan secara jelas dan terarah, faktual dan sistematis. Dalam konteks inilah keberadaan Bimbingan dan Konseling di sekolah menjadi urgen disamping proses pembelajaran. Bahkan saat ini hubungan tiga pilar pendidikan (Pembelajaran, Bimbingan dan Konseling, dan Manajemen / Supervisi) menjadi sangat urgen untuk dikelola secara koordinatif, kooperatif, dan sinergis, agar mendorong pencapaian kompetensi peserta didik secara optimal.

Namun kenyataan menunjukkan bahwa belum banyak dijumpai manajemen BK di SLTA khususnya yang dilaksanakan secara terarah, sistematis, dan bahkan belum pula didasarkan pada kebutuhan riil sekolah tersebut. Umumnya kepala sekolah walaupun sebagai manajer justru cenderung menyerahkan sepenuhnya penyelenggaraan BK diurusi Guru BK sendiri, mulai dari perencanaan, pengorganisasian, sampai pada penilaian. Akhirnya masalahmasalah organisasi, administrasi, maupun sarana-prasarana misalnya hanya ditata sekedarnya, bahkan cenderung tidak memadai. Apapun alasan dan latar belakangnya kondisi tersebut jelas tidak mendukung untuk berkembangnya manajemen bimbingan dan konseling yang bermutu, yang pada gilirannya dayaguna bimbingan dan konseling terhadap pencapaian kompetensi bagi siswa akan terabaikan.

Memperhatikan urgensi bimbingan dan konseling baik untuk kepentingan peserta didik maupun kondisi pengembangan manajemen BK yang saat ini masih terabaikan, maka peneliti menganggap sangat perlu untuk mengkaji manajemen BK di sekolah melalui penelitian dengan judul "Manajemen Bimbingan dan Konseling di SMA Melati Binjai Tahun Pelajaran 2016/2017".

\section{Pengertian Manajemen}

Manajemen adalah proses perencanaan, pengorganisasian, pengarahan dan pengawasan usaha-usaha para anggota organisasi dan penggunaan sumber daya-sumber daya organisasi lainnya agar mencapai tujuan organisasi yang telah ditetapkan.

Berdasarkan definisi di atas, adapt disimpulkan bahwa manajemen melibatkan pencapaian "tujuan-tujuan organisasi yang telah ditetapkan" (stated goals). Ini mengandung arti bahwa para manajer organisasi apapun berupaya untuk mencapai berbagai hasil akhir spesifik. Hasil-hasil akhir ini tentu saja unik bagi masing-masing organisasi. Bagaimanapun juga, apapun tujuan yang telah ditetapkan organisasi tertentu, manajemen merupakan proses untuk mencapai tujuan. 
Atas dasar uraian di atas, kita bisa menyimpulkan bahwa pada dasarnya manajemen dapat didefinisikan sebagai bekerja dengan orang-orang untuk menentukan, menginterpretasikan dan mencapai tujuan-tujuan organisasi dengan pelaksanaan fungsi-fungsi perencanaan (planning),pengorganisasian (organizing), penyusunan personalia atau kepegawaian (staffing), pengarahan dan kepemimpinan (leading) dan pengawasan (controlling).

\section{Fungsi Manajemen}

Manajemen dibutuhkan oleh semua organisasi, karena tanpa manajemen, semua usaha akan sia-sia dan pencapaian tujuan akan lebih sulit. Ada tiga alasan utama diperlukannya manajemen:

1) Untuk mencapai tujuan. Manajemen dibutuhkan untuk mencapai tujuan organisasi dan pribadi.

2) Untuk menjaga keseimbangan di antara tujuan-tujuan yang saling bertentangan. Manajemen dibutuhkan untuk menjaga keseimbangan antara tujuan-tujuan, sasaran-sasaran dan kegiatan-kegiatan yang saling bertentangan dari pihak-pihak yang berkepentingan dalam organisasi, seperti pemilik dan karyawan, maupun kreditur, pelanggan, konsumen, supplier, serikat kerja, assosiasi perdagangan, masyarakat dan pemerintah.

3) Untuk mencapai efisiensi don efektivitas. Suatu kerja organisasi dapat diukur dengan banyak cara yang berbeda. Salah satu cara yang umum adalah efisiensi dan efektivitas.

Fungsi-fungsi manajemen adalah serangkaian kegiatan yang dijalankan dalam manajemen berdasarkan fungsinya masing-masing dan mengikuti satu tahapan-tahapan tertentu dalam pelaksanaannya. Fungsi-fungsi manajemen dapat diuraikan sebagai berikut:

a. Perencanaan atau Planning, yaitu proses yang menyangkut upaya yang dilakukan untuk mengantisipasi kecenderungan di masa yang akan datang dan penentuan strategi dan taktik yang tepat untuk mewujudkan target dan tujuan organisasi: 1) Menetapkan tujuan dan target, 2) Merumuskan strategi untuk mencapai tujuan dan target, 3) Menentukan sumber-sumber daya yang diperlukan, 4) Menetapkan standar/indikator keberhasilan dalam pencapaian tujuan dan target bisnis.

b. Pengorganisasian atau Organizing, yaitu proses yang menyangkut bagaimana strategi dan taktik yang telah dirumuskan dalam perencanaan didesain dalam sebuah struktur organisasi yang tepat dan tangguh, sistem dan lingkungan organisasi yang kondusif, dan bisa memastikan bahwa semua pihak dalam organisasi bisa bekerja secara efektif dan efisien guna pencapaian tujuan organisasi.

c. Pengimplementasian atau Directing, yaitu proses implementasi program agar bisa 
dijalankan oleh seluruh pihak dalam organisasi serta proses memotivasi agar semua pihak tersebut dapat menjalankan tanggung jawabnya dengan penuh kesadaran dan produktivitas yang tinggi.

d. Pengendalian dan Pengawasan atau Controlling, yaitu proses yang dilakukan untuk memastikan seluruh rangkaian kegiatan yang telah direncanakan, diorganisasikan, dan diimplementasikan bisa berjalan sesuai dengan target yang diharapkan sekalipun berbagai perubahan terjadi dalam lingkungan dunia bisnis yang dihadapi.

\section{Bimbingan dan Konseling}

Bimbingan adalah suatu proses membantu individu melalui usaha sendiri untuk menemukan dan mengembangkan kemmapuannya agar memperoleh kebahagiaan pribadi dan kemanfaatan sosial.

Bimbingan dan konseling berasal dari dua kata yaitu bimbingan dan konseling. Bimbingan merupakan terjemahan dari guidance yang di dalamnya terkandung beberapa makna.

Pengertian bimbingan adalah proses bantuan terhadap individu agar ia memahami dirinya dan dunianya, sehingga dengan demikian ia dapat memanfaatkan potensi-potesinya. Konseling adalah upaya bantuan yang diberikan seorang pembimbing yang terlatih dan berpengalaman, terhadap individu yang membutuhkannya agar individu tersebut berkembang potensinya secara optimal.

Berdasarkan defenisi Bimbingan dan Konseling di atas, dapat disimpulkan bahwa Bimbingan Konseling bertujuan untuk:

1. Menemukan pribadi maksudnya adalah siswa mengenal kekuatan dan kelemahan diri sendiri serta menerima secara positif dan dinamis sebagai modal pengembangan lebih lanjut.

2. Mengenal lingkungan maksudnya adalah agar siswa mengenal secara obyektif lingkungan sosial dan ekonomi, lingkungan budaya dengan nilai-nilai norma maupun lingkungan fisik dan menerima semua kondisi lingkungan.

3. Merencanakan masa depan, maksudnya adalah agar siswa mampu mempertimbangkan dan mengambil keputusan tentang masa depannya sendiri, baik yang menyangkut pendidikan karier dan keluarga.

Tujuan umum pelayan bimbingan dan konseling adalah sama dengan tujuan pendidikan, sebagaimana dinyatakan dalam UU NO 20 tahun 2003 tentang sistem pendidikan nasional yaitu terwujudnya manusia indonesia seutuhnya yang cerdas, yang beriman, dan 
bertakwa kepada tuhan yang maha esa dan berbudi luhur, memiliki pengetahuan dan keterampilan, sehat jasmani dan rohani.

\section{Manajemen Bimbingan dan Konseling}

Sebelum membicarakan bagaimana manajemen BK yang baik, terarah dan sistematis, maka ada baiknya menyimak lebih dahulu beberapa kesalahpahaman dalam memandang bimbingan dan konseling. Beberapa kesalahpahaman menurut Prayitno dan Erman Amti adalah sebagi berikut:

1. Bimbingan dan Konseling disamakan saja dengan atau dipisahkan sama sekali dari pendidikan.

2. Bimbingan dan Konseling dianggap semata-mata sebagai proses pemberian nasihat.

3. Bimbingan dan Konseling dibatasi pada hanya menangani masalah yang bersifat insidental.

4. Bimbingan dan Konseling dibatasi hanya untuk klien-klien tertentu saja.

5. Bimbingan dan Konseling melayani "orang sakit" dan / atau "kurang normal".

6. Bimbingan dan Konseling bekerja sendiri.

7. Konselor di sekolah dianggap sebagai "polisi sekolah".

8. Konselor harus aktif sedang pihak lain pasif.

9. Pekerjaan Bimbingan dan Konseling dapat dilakukan oleh siapa saja.

10. Pelayanan Bimbingan dan Konseling berpusat pada keluhan pertama saja.

11. Menyamakan pekerjaan Bimbingan dan Konseling dengan pekerjaan dokter atau psikiater.

12. Menganggap hasil pekerjaan Bimbingan dan Konseling harus segera dilihat.

13. Menyamarataklan cara pemecahan masalah bagi semua klien.

14. Memusatkan usaha Bimbingan dan Konseling hanya pada penggunaan Instrumentasi Bimbingan dan Konseling (Misalnya Tes, Inventori, Angket, dan Alat Pengungkap lainnya).

15. Bimbingan Konseling dibatasi pada hanya menangani masalah-masalah yang ringan saja.

Kesalahpahaman ini dimungkinkan terjadi, mengingat pelayanan bimbingan dan konseling dalam waktu yang relatif tidak begitu lama telah tersebar ke sekolah-sekolah di seluruh pelosok tanah air. Selanjutnya oleh berbagai pihak dengan latar belakang yang sangat bervariasi, dan sebagian lagi bukan berlatar belakang pendidikan bidang bimbingan dan konseling, bahkan literatur yang memberikan wawasan, pengertian, dan seluk beluk teori dan praktik bimbingan dan konseling yang dapat memperluas dan mengarahkan pemahaman yang benar juga masih sangat kurang. Inilah yang perlu diluruskan dan kesalahpahaman tersebut dicegah penyebarannya atau memperkuat manajemennya. 
Oleh karena itu, Bimbingan dan Konseling harus dikelola dengan baik, sehingga kesalahpahaman tentang Bimbingan dan Konseling yang selama ini terjadi dapat diluruskan dan mendapatkan hasil ang optimal. Pengelolaan pada dasarnya terfokus pada empat pilar kegiatan, yaitu perencanaan (planning), pengorganisasian (organizing), pelaksanaan (actuating), dan pengontrolan (controlling). Pengelolaan berbasis kinerja mendasarkan pelaksanaannya pada kinerja konselor berkenaan dengan POAC penyelenggaraan pelayanan konseling terhadap sasaran pelayanan yang menjadi tanggung jawabnya. Arah POAC adalah:

1. Planning: Bagaimana konselor membuat perencanaan layanan dan kegiatan pendukung, mulai dari membuat program tahunan, semesteran, bulanan, dan mingguan sampai dengan harian (berupa SATLAN dan SATKUNG).

2. Organizing: Bagaimana konselor mengorganisasikan berbagai unsur dan sarana yang akan dilibatkan di dalam kegiatan. Unsur-unsur ini meliputi unsur-unsur personal (seperti peranan pimpinan sekolah, wali kelas, guru, siswa, orang tua), sarana fisik dan lingkungan (seperti ruangan dan mobiler, alat bantu seperti komputer, film, dan objek-objek yang dikunjungi), urusan administrasi, dana, dan lain lain.

3. Actuating: Bagaimana konselor mewujudkan dalam praktik jenis-jenis layanan dan/atau kegiatan pendukung melalui SPO masing-masing kegiatan yang telah direncanakan dan diorganisasikan.

4. Controlling: Bagaimana konselor mengontrol praktik pelayanannya dalam bentuk penilaian hasil dan proses kegiatan serta mempertanggungjawabkannya kepada stakeholders. Kegiatan ini melibatkan peran pengawasan dan pembinaan baik dari pihak interen maupun eksteren satuan pendidikan, serta organisasi profesi.

Kinerja guru BK ditujukan kepada seluruh sasaran pelayanan siswa asuh yang menjadi tanggung jawabnya. Volume kerja konselor secara berkala dipertanggungjawabkan kepada pimpinan lembaga satuan pendidikan, Oleh karena itu diperlukan manajemen BK yang handal untuk memberikan pelayanan BK ang efektif dan efisien di sekolah.

Manajemen BK yang dimaksudkan adalah rangkaian kegiatan yang dilakukan oleh Kepala Sekolah baik secara sendiri termasuk bersama-sama dengan unsur lain dalam merencanakan, mengorganisasikan, memimpin dan mengendalikan upaya organisasi Bimbingan dan Konseling dengan segala aspeknya agar tujuan tercapai secara efektif dan efisien. Dengan demikian menyelenggarakan manajemen Bimbingan dan Konseling tidak lain adalah rangkaian kegiatan merencanakan, mengorganisasikan, memimpin dan mengendalikan upaya Bimbingan dan Konseling secara fleksibel dan partisipatif yang didasarkan pada 
perundang-undangan yang berlaku, dan disesuaikan dengan kebutuhan dan kondisi sekolah yang bersangkutan.

Penyelenggaraan Manajemen BK merupakan bagian dari pelaksanaan BK yang diterapkan di sekolah tersebut, karena Bimbingan dan Konseling adalah merupakan bagian dari proses yang harus digerakkan. Bercermin dan kondisi di lapangan tentang masih belum optimalnya penyelenggaraan pelayanan bimbingan dan konseling serta banyaknya kesalahpahaman yang muncul dalam memandang bimbingan dan konseling jelas menunjukkan bahwa penyelenggaraan bimbingan dan konseling perlu diperkuat dengan manajemen. Artinya segala langkah yang dilakukan dikaitkan dengan karakteristik manajemen sebagaimana diuraikan di atas.

Dilihat dari aspek-aspek manajemen bimbingan konseling yakni : (a) Perencanaan (b) Pengorganisasian (c) Operasionalisasi (d) Pengarahan (e) Supervisi (f) Penilaian (g) Fasilitas. Untuk itu uraian berikut menggambarkan bagaimana menyelenggarakan manajemen Bimbingan Konseling sebagai berikut:

1. Perencanaan

2. Pengorganisasian

3. Menggerakkan, mengarahakan dan melakukan supervisi operasional layanan/ kegitaan pendukung.

4. Menyelenggarakan penilaian.

5. Menyediakan fasilitas

\section{METODE PENELITIAN}

Tempat pelaksanaan penelitian adalah SMA Melati Binjai . Alasan memilih sekolah ini sebagai lokasi penelitian adalah dengan pertimbangan bahwa pelaksanaan bimbingan dan konseling sudah ada. Sekolah ini dalam proses pembelajaran menyediakan jam khusus tatap muka, terjadwal sesuai dengan program bimbingan dan konseling. Penelitian ini akan dilakukan pada bulan Januari 2017.

Subjek disebut juga sebagai participant dalam penelitian. Partisipan digunakan, terutama apabila subjek mewakili suatu kelompok tertentu, dan hubungan antara peneliti dengan subjek penelitian dianggap bermakna bagi subjek. Istilah informan dan partisipan tersebut secara substansial dipandang sebagai instrumen utama dalam penelitian kualitatif. Sebagai informasi data penelitian ini, penulis mengambil 3 sumber informan data yaitu:

1. Kepala SMA Melati Binjai sebagai penanggung jawab penyelenggaraan bimbingan dan konseling sekolah. 
2. Konselor sekolah tentang pelaksanaan pelayanan BK di SMA Melati Binjai.

3. Siswa SMA Melati Binjai sebagai sasaran layanan BK.

4. Staf administrasi SMA Melati Binjai.

Sesuai dengan judul penelitian "Manajemen Bimbingan dan Konseling di SMA Melati Binjai Tahun Pelajaran 2016/2017" maka penelitian ini dilakukan dengan menggunakan rancangan penelitian yang bersifat kualitatif. Datanya diperoleh dengan melakukan:

1. Wawancara yaitu percakapan dengan maksud tertentu yang dilakukan oleh dua pihak, yaitu pewawancara (interviewer) yang mengajukan pertanyaan, dan orang yang diwawancarai (interviewer) yang memberikan jawaban atas pertanyaan itu. Wawancara ini dilakukan kepada:

a. Kepala SMA Melati Binjai tentang pelaksanaan bimbingan dan konseling di SMA Melati Binjai.

b. Konselor sekolah dalam melaksanakan tugas dan tanggjawab bimbingan dan konseling di SMA Melati Binjai.

c. Siswa sebagai sasaran layanan BK di SMA Melati Binjai.

d. Staf administrasi yang memegang data di SMA Melati Binjai .

2. Observasi adalah kemampuan seseorang untuk menggunakan pengamatannya melalui hasil kerja pancaindra mata serta dibantu dengan pancaindra lainnya. Pengamatan juga digunakan sebagai metode utama, di samping wawancara tak berstruktur, untuk mengumpulkan data. Observasi ini dilakukan:

a. Kepada konselor sekolah dalam pelaksanaan tugas dan tanggung jawab bimbingan dan konseling khususnya pelaksanaan BK di SMA Melati Binjai.

b. Siswa sebagai sasaran layanan BK di SMA Melati Binjai .

3. Studi dokumen yang dilakukan dengan mengumpulkan segala bentuk fisik yang terkait dengan pelaksanaan program BK di SMA Melati Binjai, terdiri dari prin out program, hasil AUM Umum dan PTSDL, hasil sosiometri, himpunan data siswa, poto pelaksanaan layanan, dan segala bentuk fisik yang terkait dengan pelaksanaan program BK di SMA Melati Binjai.

Keseluruhan data maupun sejumlah informasi yang berhasil dihimpun dari lokasi penelitian, maka data dalam penelitian ini akan diolah sesuai dengan jenis penelitian. Adapun penelitian ini bersifat kualitatif. Adapun yang dimaksud dengan peneiitian kualitatif adalah : "Prosedur penelitian yang menghasilkan data deskriptif berupa kata-kata tertulis atau lisan dari orang-orang dan perilaku yang dapat diamati". 
Dengan demikian dalam mengolah dan menganalisa data penelitian ini digunakan prosedur penelitian kualitatif, yakni dengan menjelaskan atau memaparkan penelitian ini apa adanya serta menarik kesimpulan dengan menggunakan metode deduktif. Prosedur pelaksanaan penelitian dilakukan dengan cara mereduksi data, menyajikan data, dan membuat kesimpulan. Proses analisa ini berlangsung secara sirkuler selama penelitian ini berlangsung. Penjelasan ketiga tahapan ini adalah sebagai berikut:

1. Mereduksi Data

Mereduksi data adalah proses pemilihan, memfokuskan pada penyederhanaan, pengabstrakan dan transformasi data mentah/kasar yang muncul dari catatan-catatan tertulis di lapangan. Reduksi data merupakan suatu bentuk analisis yang menajamkan, menonjolkan, hal-hal yang penting, menggolongkan, mengarahkan, membuang yang tidak di butuhkan dan mengorganisasikan data agar lebih sistematis, sehingga dapat dibuat suatu kesimpulan yang bermakna. Data yang telah direduksi dapat memberikan gambaran yang lebih tajam tentang hasil pengamatan.

2. Menyajikan Data

Menyajikan data adalah proses pemberian sekumpulan informasi yang disusun dan memungkinkan untuk penarikan kesimpulan. Jadi penyajian data ini merupakan gambaran secara keseluruhan dari sekelompok data yang diperoleh agar mudah dibaca secara menyeluruh.

3. Membuat Kesimpulan.

Pada mulanya data terwujud dari kata - kata, tulisan dan tingkah laku perbuatan yang telah dikemukakan dalam penelitian ini diperoleh melalui hasil observasi, interview atau wawancara dan studi dokumenter, sebenarnya sudah dapat memberikan kesimpulan, tetapi sifatnya masih sederhana. Dengan bertambahnya data yang dikumpulkan secara sirkuler bersama reduksi dan penyajian, maka kesimpulan merupakan konfigurasi yang utuh.

Keabsahan data yang diperoleh terutama dari hasil wawancara, dilakukan melalui teknik triangulasi. Melalui triangulasi data dicek kembali derajat kepercayaan sebagai suatu informasi. Patton dalam Lexy J. Moleong menjelaskan bahwa hal ini dapat dicapai dengan jalan :

1. Membandingkan data hasil wawancara.

2. Membandingkan dengan apa yang dikatakan orang di depan umum dengan apa yang di katakan secara pribadi.

3. Membandingkan dengan apa yang di katakan orang-orang tentang situasi penelitian dengan apa yang di katakan sepanjang waktu. 
4. Membandingkan keadaan dan perspektif seseorang dengan berbagai pendapat dan pandangan orang seperti rakyat biasa.

Dengan demikian data yang diperoleh pada setiap wawancara bila memerlukan pendalaman dilakukan melalui langkah-langkah seperti diuraikan pada kutipan di atas. Keabsahan data yang diperoleh di lapangan diperiksa dengan menggunakan teknik-teknik sebagai berikut :

1. Pertanyaan yang sama diajukan kepada informan yang berbeda melalui wawancara terstruktur dan tidak berstruktur. Wawancara berstruktur diajukan saat pertama kali wawancara, dan pada wawancara berikutnya kepada informan yang sama dilakukan wawancara tidak berstruktur dengan materi pertanyaan yang sama.

2. Observasi terhadap bukti-bukti fisik kegiatan dalam melaksanakan layanan informasi kepada mahasiswa sekaligus mengecek kesesuaian apa yang diungkapkan dengan apa yang diungkapkan dengan apa yang dilaksanakan, sehingga didapatkan data yang akurat.

3. Mengkonfirmasikan hasil temuan dengan informasi penelitian. Maksudnya setelah data yang diperoleh melalui wawancara dan observasi (pengamatan) di lokasi penelitian, dilakukan rechecking (meneliti ulang) terhadap kebeneran data yang didapat. Kalau responden tidak setuju dengan data tersebut, maka dilakukan revisi bagaimana data informasi yang sebenarnya.

Menurut Nasution : "Validitas membuktikan bahwa apa yang di amati oleh peneliti sesuai dengan apa yang sesungguhnya ada dalam dunia nyata dan apakah penjelasan yang diberikan tentang dunia memang sesuai dengan yang sebenarnya ada atau terjadi”.

Nasution mengemukakan: "Validitas membuktikan bahwa apa yang di amati oleh peneliti sesuai dengan apa yang sesungguhnya ada dalam dunia nyata dan apakah penjelasan yang diberikan tentang dunia memang sesuai dengan yang sebenarnya ada atau terjadi”.

Validitas dalam penelitian ilmiah dapat di bedakan menjadi dua macam yaitu validitas internal (berkenaan dengan instrumentasi) dan validitas ekternal (berkenaan dengan generalisasi). Validitas internal dalam penelitian kualitatif adalah kesesuaianj konsep penelitian dengan konsep responden, sedang validitas eksternal berarti adanya kecocokan dan kemungkinan hasil penelitian dapat di aplikasikan dalam konteks dan situasi tertentu. Validitas diusahakan dapat memenuhi kriteria-kriteria sebagaimaa yang di kemukakan oleh Nasution yaitu : "Kredibilitas, transfermabilitas, dependabilitas, dan konfirmabilitas". Untuk lebuih memahami terhadap beberapa istilah yang telah dikemukakan di atas, maka dapat diuraikan sebagai berikut: 
a. Kepercayaan/kebenaran (Kredebilitas) Untuk mencapai kredebilitas yang diharapkan dapat dilakukan dengan cara sebagai berikut:

b. Triangulasi adalah mencek kebenaran data yang diperoleh dengan cara membandingkan dengan data yang diperoleh dari sumber lain tentang hal yang sama pada berbagai fase penelitian lapangan dalam waktu yang berlainan dan dengan menggunakan metode yang berlainan.

c. Peer Deberfing adalah pembicaraan dengan sejawat yakni kegiatan untuk membahas dan mendiskusikan hasil penelitian dengan teman-teman sejawat atau kolega, hal ini dimaksudkan untuk memperoleh masukan-masukan yang netral dan objektif baik berupa saran maupun kritikan-kritikan sehingga pada gilirannya dapat meningkatkan tingkat kepercayaan penelitian.

d. Penggunaan bahan referensi, dilakukan dengan menggunakan hasil foto.

e. Member check, dilakukan dengan mengkonfirmasikan hasil-hasil penelitian dengan informasi ang diperoleh untuk dinilai keabsahannya.

f. Keteralihan (Transfermabilitas) Nasution mengemukakan bahwa: bagi peneliti kualitatif, bergantung kepada sipemakai, hingga manakala hasil penelitian itu dapat mereka gunakan dalam konteks dan situasi tertentu. Untuk itu transferabilitas hasil penelitian baru ada apabila pemakai melihat ada situasi yang identik dengan permasalahan pengembangan manajemen pembelajaran, meskipun diakui bahwa tidak ada situasi yang sama persis pada tempat dan kondisi yang berlainan. Faisal memberikan penegasan pada transfermabilitas yaitu : Standar ini sesungguhnya merupakan pertanyaan empiris (emprical question) yang tak dapat dijawab oleh peneliti kualitatif itu sendiri. Yang bisa menjawab dan menilainya adalah para pembaca laporan penelitian. Bila pembaca laporan penelitian memperoleh gambaran yang sedemikian jelas ke latar atau konteks "semacam apa" sesuatu hasil penelitian dapat diberlakukan (transferable), maka laporan tersebut memenuhi standar transferabilitas.

g. Kehandalan/ketercapaian (Dependabilitas dan Konfirmabilitas).

Pencapaian dependeable (reliabel) penelitian ini diusahakan dengan menjaga pengumpulan data, konsep, penelitian, serta kesimpulan tetap konsisten. Dependabilitas ini dapat dilakukan dengan mempelajari laporan-laporan lapangan, sampai laporan penelitian selesai untuk mengetahui konsistensi peneliti dalam setiap aspek. Sedangkan pencapaian konfirmabilitas diusahakan agar hasil penelitian ini sesuai dengan data serta merupakan suatu kebutuhan. 


\section{HASIL DAN PEMBAHASAN}

\section{Visi Pelayanan Bimbingan dan Konseling SMA Melati Binjai}

Tujuan pendidikan tingkat satuan pendidikan dasar dan menengah adalah meningkatkan kecerdasan, pengetahuan, kepribadian, akhlak mulia, serta keterampilan untuk hidup mandiri dan mengikuti pendidikan lebih lanjut.

\section{Misi Pelayanan Bimbingan dan Konseling SMA Melati Binjai}

- Melaksanakan Pembelajaran dan bimbingan secara efektif sehingga setiap siswa dapat berkembang secara optimal sesuai dengan potensi yang dimilikinya.

- Akhlakul karimah merupakan wujud dari kultur Madrasah sebagai cerminan dari keimanan dan ketaqwaan.

- Nilai semangat kemandirian dan keunggulan tumbuh dan berkembang pada seluruh warga Madrasah, baik dalam bidang akademis maupun nonakademis.

- Disiplin, motif berprestasi, dan etos kerja yang tinggi merupakan landasan dalam pelayanan dan pengabdian.

- Anatara semua personal Madrasah tercipta dan terbina kerjasama dan hubungan yang harmonis.

- Loyalitas dan dedikasi yang tinggi seluruh warga Madrasah dalam peningkatan mutu pelayanan pendidikan.

- Akuntabilitas dan transparansi merupakan manajemen pengelolaan Madrasah dengan menerapkan manajemen partisipatif dari seluruh stakeholders Madrasah.

\section{Tujuan}

Adapun tujuan SMA MELATI Binjai adalah sebagai berikut:

- Terciptanya warga Madrasah yang sehat jasmani dan rohani.

- Terwujudnya iklim Madrasah yang sejuk dan harmonis dalam suasana tatakrama dan budi pekerti yang dilandasi nilai-nilai akhlakul karimah.

- Berkembangnya kecerdasan ilahiyah dan kecerdasan spiritual guna mencapai kepribadian yang mantap dan mandiri.

- Meningkatnya pelayanan pendidikan terhadap peserta didik, masyarakat dan komponen pendidikan lainnya.

- Terwujudnya siswa-siswi yang memiliki prestasi akademis, cerdas intelektual, cerdas emosional, dan cerdas spiritual serta berketrampilan yang berharga dan berdaya guna.

- Terbinanya pengawasan, pengeloaan, dan pengorganisasian Madrasah secara akuntabel dan transparan dalam upaya peningkatan mutu pendidikan. 
- Terjalinnya hubungan dan kerjasama yang harmonis antara Madrasah dan seluruh stakeholders Madrasah.

- Terwujudnya Madrasah yang menjadi dambaan siswa, masyarakat dan lingkungan.

\section{KESIMPULAN}

Setelah melakukan penelitian tentang Manajemen Bimbingan dan Konseling di SMA Melati Binjai, dan melakukan pembahasan, maka manajemen Bimbingan dan Konseling di SMA Melati Binjai dapat disimpulkan:

Prinsip pendidikan dan pembelajaran di SMA MELATI Binjai adalah:

1. Menjunjung tinggi nilai ilmu, belajar, mengajar dan melaksanakan pendidikan sebagai misi Islam melalui Allah dan Rasul-Nya.

2. Melaksanakan pendidikan dan mendukung pendidikan dilandasi keiklasan niat menjalankan perintah agama sebagai ibadah yang sangat penting.

3. Mengikuti pendidikan dilandasi dengan tujuan yang mulia untuk membina keimanan dan ketakwaan melalui ilmu dan teknologi untuk kebahagian dunia dan akhirat.

4. Mengutamakan kualitas dan kuantitas.

5. Mengandalkan kerja keras dari kelengkapan fasilitas.

6. Mengutamakan kemandirian dari ketergantungan.

7. Berlandaskan rido Allah untuk memperoleh ilmu dan hasil pendidikan yang bermanfaat.

Jumlah guru BK 1 orang dengan jumlah siswa 242 orang, berdasarkan undang-undang bahwa rasio guru BK dengan siswa adalah 1 banding 150. Berdasarkan hal ini, berarti jumlah guru BK di SMA MELATI Binjai masih kurang.

Visi Pelayanan Bimbingan dan Konseling SMA MELATI Binjai: Tujuan pendidikan tingkat satuan pendidikan dasar dan menengah adalah meningkatkan kecerdasan, pengetahuan, kepribadian, akhlak mulia, serta keterampilan untuk hidup mandiri dan mengikuti pendidikan lebih lanjut. Misi Pelayanan Bimbingan dan Konseling SMA MELATI Binjai:

1. Melaksanakan Pembelajaran dan bimbingan secara efektif sehingga setiap siswa dapat berkembang secara optimal sesuai dengan potensi yang dimilikinya.

2. Akhlakul karimah merupakan wujud dari kultur Madrasah sebagai cerminan dari keimanan dan ketaqwaan.

3. Nilai semangat kemandirian dan keunggulan tumbuh dan berkembang pada seluruh warga Madrasah, baik dalam bidang akademis maupun non akademis.

4. Disiplin, motif berprestasi, dan etos kerja yang tinggi merupakan landasan dalam pelayanan dan pengabdian. 
5. Anatara semua personal Madrasah tercipta dan terbina kerjasama dan hubungan yang harmonis.

6. Loyalitas dan dedikasi yang tinggi seluruh warga Madrasah dalam peningkatan mutu pelayanan pendidikan.

7. Akuntabilitas dan transparansi merupakan manajemen pengelolaan Madrasah dengan menerapkan manajemen partisipatif dari seluruh stakeholders.

8. Bidang pengembangan yang dilakukan di SMA MELATI Binjai adalah Pribadi, sosial, belajar, dan karir.

9. Pelaksanaan BK di SMA MELATI Binjai adalah: Kepala Sekolah sebagai penanggung jawab, Guru BK sebagai perencana sekaligus pelaksana, guru amat pelajaran sebagai mitra kerja, siswa sebagai sasaran layanan.

\section{REFERENSI}

Afifuddin \& Beni Ahmad Saebani. 2009. Metodologi Penelitian Kualitatif , Bandung: Pustaka Setia.

Arifin, Anwar. 2003. Memahami Paradigma Baru Pendidikan Nasional, Jakarta: Rineka Cipta.

Bungin, Burhan. 2010. Penelitian Kualitatif. Jakarta: Kencana.

Faisal, Sanafiah. 2000. Penelitian Kualitatif (Dasar-Dasar Dan Aplikasi),(Malang:Yayasan Asih Asah Asuh Malang.

Hallen. A. 2005. Bimbingan dan Konseling, Ciputat: Quantum Teaching.

Lubis, Syauful Akhyar. 2011. Konseling Islami dan kesehatan mental, Bandung: Citapusaka.

Moleong, J. Lexy. 2000. Metodologi Penelitian Kualitatif Bandung: Remaja Rosdakarya,. . 2010. Metodologi Penelitian Kualitatif, Bandung: Remaja Rosdakarya.

Nasution. 2000. Metode Penelitian Naturalistik Kualitatif, Bandung: Alfa Beta.

Pembudi, Bambang Setyo. 2013. Pengantar Manajemen, Universitas Trunojoyo.

Prayitno \& Erman Amti. 2001. Dasar-dasar Bimbingan dan Konseling, Jakart:. Rineka Cipta.

Prayitno. 2001. Panduan Kegiatan Pengawasan Bimbingan dan Konseling di Sekolah, Jakarta: Rineka Cipta.

Prayitno. 2001. Panduan Kegiatan Pengawasan dan Konseling di Sekolah. Jakarta: Rineka Cipta. 
Sukmadinata, Nana Syaodih. 2006. Metode Penelitian Pendidikan, Bandung: Remaja Rosdakarya.

Willis, Sofyan S., 2004. Konseling Individual (Teori dan Praktek), Bandung: Alfabeta.

Yusuf, Samsu \& A. Juntika Nurihsan. 2005. Landasan Bimbingan dan Konseling, Bandung: Remaja Rosdakarya, 